\title{
Aloe vera extract reduces 8-0xo-2'-deoxyguanosine levels and improves total antioxidants in streptozotocin-induced diabetic rats
}

\author{
Wulan Christijanti*, Aditya Marianti*, and Wiwi Isnaeni*
}

\begin{abstract}
* Department of Biology, Faculty of Mathematics and Natural Sciences, Semarang State University

\section{Correspondence:}

drh. Wulan Christijanti, MSi

Department of Biology,

Faculty of Mathematics and Natural

Sciences,

Semarang State University

Kampus FMIPA

Jl. Raya Sekaran Gunungpati

Semarang

Phone: 02486458295

Mobile: +62815 6536227

Email: wchristijanti@gmail.com

Univ Med 2017;36:34-41

DOI: 10.18051/UnivMed.2017.v36.34-41 pISSN: 1907-3062 / eISSN: 2407-2230

Received December 9, 2016

\section{BACKGROUND}

Diabetes mellitus is a chronic disease caused by lack of insulin production in the pancreas or by insulin resistance, the disease being characterized by elevated blood glucose levels. Hyperglycemia in diabetes could lead to oxidative stress due to the rise in 8-oxo-2'-deoxyguanosine (8-oxo-dG) levels and the decrease in levels of total antioxidant status (TAS). The purpose of this study was to assess the effect Aloe vera extract on 8-oxo$\mathrm{dG}$ level and total antioxidant status in diabetic rat testis.

\section{METHODS}

This was an experimental laboratory study with 20 rat samples which were divided into 4 groups (1 control group and 3 treatment groups). Diabetes was induced in the rats by streptozotocin (STZ) at $65 \mathrm{mg} / \mathrm{kgBW}$. The diabetic rats were then treated for 28 days with Aloe vera extract at $0 \mathrm{mg}$ (P0), $200 \mathrm{mg}$ rind (P1), $200 \mathrm{mg}$ pulp (P2), respectively. The level of 8 -oxo-dG was measured by ELISA and total antioxidant status with 2,2' -azino-bis (3-ethylbenzothiazoline-6-sulfonic acid (ABTS). Data were analyzed with ANOVA and Least Significant Difference Advanced Test at $\mathrm{p}<0.05$.
\end{abstract}

Accepted for publication April 7, 2017

This open access article is distributed under a Creative Commons Attribution-Non Commercial-Share Alike 4.0 International License

\section{RESULTS}

8-Oxo-dG levels were significantly different between the control group and both P0 and P2, but not between the control group and P1. Among the treatment groups the 8-oxo-dG levels were significantly different. Mean total antioxidant status was significantly different between control and treatment groups, and also between treatment groups $(\mathrm{p}<0.05)$.

\section{CONCLUSIONS}

Aloe vera extract reduced free radicals (level of 8-oxo-dG) and increased the total antioxidant status in diabetic rat testis.

Keywords: Aloe vera, 8-oxo-dG, total antioxidants, diabetes mellitus 


\section{INTRODUCTION}

Hyperglycemia in diabetes leads to oxidative stress resulting from stimulation of the polyol pathway, the formation of advanced glycation end products (AGEs), protein kinase $\mathrm{C}$ (PKC) and the further formation of reactive oxygen species (ROS). ${ }^{(1)}$ Increased ROS production in diabetics could potentially accelerate the oxidative damage to macromolecules such as lipids, proteins and DNA. Mitochondria and the nucleus are the main targets of oxidative stress, the former having a variety of enzymes to fix DNA modifications due to induction of oxidants. ${ }^{(2)} 8$-Oxo-7,8-dihydro2'-deoxyguanosine (8-oxo-2'-deoxyguanosine, 8oxo-dG) modified by ROS is a sensitive index of oxidative DNA damage. ${ }^{(3)}$

According to several studies, the concentrations of 8-oxo-dG of serum ${ }^{(4)}$ and urine of patients ${ }^{(5)}$ as well as from tissues of diabetic rats were significantly higher than normal. ${ }^{(6)}$ Another study states that there is a positive correlation of insulin resistance with oxidative stress parameters (malondialdehyde/MDA and 8-oxo-dG), and a negative correlation with the antioxidant enzyme (superoxide dismutase/ SOD). ${ }^{(7)}$ Levels of 8-oxo-dG, which is more stable than DNA reflect the generation rate and repairs. ${ }^{(8)}$

Oxidative stress occurs when the production of free radicals is higher than the capacity of cellular antioxidants. Hyperglycemia raises oxidative stress, therefore, theoretically, diabetes patients can benefit from antioxidant supplementation. The beneficial effects of antioxidants have been reported in animal models of diabetes and in diabetes patients. ${ }^{(9)}$ Antioxidants are divided into endogenous antioxidants, such as SOD, glutathione (GSH), vitamins $\mathrm{C}$ and $\mathrm{E}$, and exogenous antioxidants (vitamin $\mathrm{E}$, vitamin $\mathrm{C}$, carotenoids and flavonoids). ${ }^{(10)}$

Administration of vitamin $\mathrm{E}$ has been shown to be beneficial in preventing cell damage by inhibiting lipid peroxidation, protein oxidation, protein glycation, and platelet aggregation. A decrease in plasma $\mathrm{F}_{2}{ }^{-}$ isoprostanes was seen in type 2 diabetic patients after six weeks of supplementation with vitamin E $600 \mathrm{mg} /$ day. ${ }^{(11)}$ Constituent antioxidants from plant material act as free radical scavengers, and can be found in various food sources such as fruits, vegetables and tea. ${ }^{(12)}$

Sources of exogenous antioxidant supplements from plants such as aloe (Aloe vera), contain natural components such as phenols, flavonoids, vitamin $\mathrm{C}$ and vitamin $\mathrm{E}$, and have been proven to reduce the levels of MDA and increase the antioxidant capacity. ${ }^{(13)}$ Aloe vera extract has an assortment of pharmacological properties which encompasses protection against radiation and antiviral, antibacterial, laxative, antioxidant, antiinflammation, anticancer, antidiabetic, antiallergic, and immunostimulant properties amongst others. ${ }^{(14)}$ Besides, the provision of Aloe vera in diabetic rats showed improvement by increasing the survival of cells of the islets of Langerhans. ${ }^{(15)}$

Research by Mohapatra et al. ${ }^{(16)}$ showed that Aloe vera extract at 150 and $300 \mathrm{mg} / \mathrm{kgBW}$ can increase the levels of SOD and GSH and can decrease lipid peroxides (MDA) in comparison with diabetic controls. Flavonoids are presumably able to bind transition metal ions, which play a role in glycation, to prevent the formation of a metal catalyst to form the hydroxyl radical, or a related species of $\mathrm{H}_{2} \mathrm{O}_{2}$. A study showed that Aloe vera gel extract significantly increased plasma total antioxidants in healthy volunteers. ${ }^{(17)}$

There is insufficient scientific evidence on the efficacy of Indonesian Aloe vera extract prepared from local cultivars and on its mechanism of action. Additional work is required to probe into the antidiabetic, antimicrobial, and antioxidant properties of Indonesian Aloe vera extract. The purpose of this study was to assess the effect of Aloe vera extract on the levels of 8oxo-dG and total antioxidant status in the testis of diabetic rats. 


\section{METHODS}

\section{Research design}

This study used an experimental post-test only control group design and was conducted in the animal breeding house, while laboratory measurements of the variables were performed in the Food and Nutrition Center at the InterUniversity Center (Pusat Antar Universitas, PAU), Gajah Mada University, Yogyakarta, from June until September 2016.

\section{Plant material}

Fresh Aloe vera leaves were collected from Bandungan district, Semarang, in June 2016 and identified at the Plant Morphology laboratory of the Biology Department, Faculty of Mathematics and Natural Sciences, Semarang State University.

\section{Preparation of Aloe vera gel extract}

Aloe vera gel was prepared from Aloe vera leaf according to a modification of a previously published procedure. ${ }^{(13)}$ Mature, healthy and fresh leaves of Aloe vera having a length of approximately $60 \mathrm{~cm}$ were washed with fresh water. The leaves were cut lengthwise into two pieces, then the thick epidermis and the solid gel in the center of the leaf were homogenized in an electric blender. The homogenate sample was extracted using $96 \%$ ethanol. The filtrate was collected and evaporated to form a gel under reduced pressure in a rotary evaporator. The gel was stored in small containers in the refrigerator until further use. An aqueous suspension was prepared by dissolving suitable amounts of the ethanolic Aloe vera leaf extract to obtain the desired concentration. The herbal solutions were prepared freshly each time and administered intragastrically. The dosing schedule used was once per day.

\section{Experimental animals}

The number of experimental animals per group was the minimum sample of five. ${ }^{(18)} \mathrm{A}$ total of 20 male Wistar rats weighing 150-200 g were randomly divided into four groups (one control group and three diabetic groups). The rats were obtained from the Food and Nutrition Center at Pusat Antar Universitas (PAU), Gajah Mada University. The animals were acclimatized for 7 days, maintained on 12 hour light-dark cycles with standard rat feed and water ad libitum.

\section{Induction of experimental diabetes}

After fasting, the rats in the diabetic group were induced into the diabetic state by intra peritoneal streptozotocin (STZ) at $65 \mathrm{mg} / \mathrm{kgBW}$ on day $8 .^{(19)}$ Seventy-two hours after the induction, blood glucose measurements were performed, to determine the presence of a hyperglycemic condition with blood glucose levels of $\geq 200 \mathrm{mg} / \mathrm{dL}$.

\section{Experimental procedure}

The rats were randomized into four groups; group 1 (K, controls) received distilled water; group 2 (P0) received STZ $65 \mathrm{mg} / \mathrm{kgBW}$ and distilled water; to group 3 (P1) was administered STZ $65 \mathrm{mg} / \mathrm{kgBW}$ and $200 \mathrm{mg} / \mathrm{kgBW}$ of rind extract, while group $4(\mathrm{P} 2)$ received STZ $65 \mathrm{mg} /$ $\mathrm{kgBW}$ and $200 \mathrm{mg} / \mathrm{kgBW}$ of pulp extract. Treatment with Aloe vera extract was performed orally for 28 days, during which period the rats received feed and water ad libitum. Blood was collected in microhematocrit tubes and was used for the estimation of glucose levels on the day before and three days after streptozotocin induction and after four weeks of treatment with Aloe vera extract. The blood glucose level of the serum samples was measured by the enzymatic glucose oxidase-peroxidase (GODPAP) colorimetric method. The animals were sacrificed by cervical decapitation. A transverse abdominal incision was made and the testes were removed from the rats and cleansed of blood. The testes were homogenized with phosphate buffer and centrifuged at $3600 \mathrm{rpm}$ to collect the supernatant. 


\section{Measurements of 8-oxo-dG an total antioxidants}

The supernatants were used for the estimation of 8-oxo-dG levels and total antioxidant status. 8-Oxo-dG levels (ng/mL) were estimated using HT 8-oxo-dG ELISA Kit II (Cat \# 4380-096-K). Total antioxidant level was measured with ABTS. The TAS was estimated using a kit (Cat\# CS0790). To the wells of a 96-well plate was added $125 \mathrm{ml}$ of reagent 1 (assay buffer) and $7.5 \mathrm{~mL}$ of either the assay standard (standard 1, water; standard 2, 0.01 mmol Trolox equivalent/L solution) or the sample, and the ûrst absorbance was read at 450 $\mathrm{nm}$. [Trolox ${ }^{\mathrm{TM}}$ is a water-soluble vitamin $\mathrm{E}$ analog and serves as a standard or control antioxidant.] Then, $18.75 \mathrm{~mL}$ of reagent 2 (2,2'azino-bis (3-ethylbenzothiazoline-6-sulfonic acid/ABTS) was added to all of the wells and the second absorbance was read exactly after 10 min. The $\Delta \mathrm{A}$ was calculated as the difference between the first and second absorbance readings of either the sample or the standard or the blank, as the case may be. The difference (A1) between the $\Delta \mathrm{A}$ of the standard 1 and the $\Delta \mathrm{A}$ of the sample was calculated. Similarly, the difference (A2) between the $\Delta \mathrm{A}$ of the standard 1 and the $\Delta \mathrm{A}$ of the standard 2 was calculated. The TAS in the tissue was equal to the A1/A2 ratio and expressed in $\mathrm{mmol} / \mathrm{L}$.

\section{Statistical analysis}

Data were processed and analyzed using SPSS version 16 software. The statistical analysis used was one way Anova and LSD at a level of significance of 0.05 .

\section{Ethical clearance}

The study was conducted after obtaining ethical clearance from Dr. Kariadi Central General Hospital and the Faculty of Medicine, Diponegoro University in Semarang, under No. 699/EC/FK-RSDK/2016.

\section{RESULTS}

Blood glucose levels before and three days after STZ induction and after four weeks of treatment with Aloe vera extract are presented in Table 1. The blood glucose levels before induction showed no significant differences between all groups $(\mathrm{p}=0.172)$. Three days after STZ induction, the glucose level in P0, P1, and $\mathrm{P} 2$ reached $>200 \mathrm{mg} / \mathrm{dL}$, indicating that the induction had successfully created diabetic rats. Moreover, treatment with Aloe vera extract for four weeks significantly decreased blood glucose levels from $>200 \mathrm{mg} / \mathrm{dL}$ to $103.39 \pm 5.80 \mathrm{mg} /$ $\mathrm{dL}(\mathrm{P} 1)$ and $125.89 \pm 5.01 \mathrm{mg} / \mathrm{dL}(\mathrm{P} 2)(\mathrm{p}<0.05)$.

On determination of serum 8-oxo-dG concentration, it was found that mean 8-oxo-dG concentrations of the control and treatment groups were $3.34 \pm 0.26 \mathrm{ng} / \mathrm{mL}, 18.55 \pm 3.18 \mathrm{ng} / \mathrm{mL}$, $4.80 \pm 0.25 \mathrm{ng} / \mathrm{mL}$ and $9.06 \pm 0.15 \mathrm{ng} / \mathrm{mL}$, respectively (Table 2). Thus serum 8 -oxo-dG concentration in the control group $(\mathrm{K})$ was significantly lower than in the diabetic groups $(\mathrm{p}=0.000)$. The free radical level in the form of $3.34 \mathrm{ng} / \mathrm{mL}$ 8-oxo-dG in the control group was significantly different from that in the treatment groups ( $\mathrm{p}<0.05$ ), except group P1. Among the treatment groups (P0, P1 and $\mathrm{P} 2)$ the free radical level also showed significant differences.

Table 1. Blood glucose level in non diabetic and diabetic rats after four weeks of treatment with Aloe vera extract

\begin{tabular}{lccccc}
\hline \multirow{2}{*}{ Blood glucose level (mg/dL) } & \multicolumn{5}{c}{ Treatm ent groups } \\
\cline { 2 - 5 } & K & P0 & P1 & P2 & P \\
\hline Before STZ induction & $6375 \pm 1.22$ & $65.28 \pm 2.71$ & $63.98 \pm 1.90$ & $66.18 \pm 1.16$ & 0.172 \\
3 days after STZ induction & $63.43 \pm 1.93$ & $215.34 \pm 7.08$ & $217.02 \pm 6.31$ & $219.51 \pm 8.61$ & 0.000 \\
4 weeks after treatm ent & $6396 \pm 1.85$ & $216.04 \pm 6.93$ & $103.39 \pm 5.80$ & $125.89 \pm 5.01$ & 0.000 \\
\hline
\end{tabular}

K: distilled water; P0: STZ $65 \mathrm{mg} / \mathrm{kgBW}$ and distilled water; P1: STZ $65 \mathrm{mg} / \mathrm{kgBW}$ and $200 \mathrm{mg} / \mathrm{kg}$ of rind extract; P2: STZ $65 \mathrm{mg} / \mathrm{kgBW}$ and $200 \mathrm{mg} / \mathrm{kgBW}$ of pulp extract; STZ = Streptozotocin; significantly different $(\mathrm{p}<0.05)$ 
Table 2. Differences in 8-oxo-dG level and total antioxidant concentrations between the control and treatment groups

\begin{tabular}{|c|c|c|c|c|c|}
\hline \multirow{2}{*}{ Variable } & \multicolumn{4}{|c|}{ Treabment gro ups } & \multirow[b]{2}{*}{$\mathbf{p}$} \\
\hline & $\bar{K}$ & P0 & Pl & $\overline{P 2}$ & \\
\hline 8-0xo-dG (ng/mL) & $3.34 \pm 0.26$ & $18.55 \pm 3.18$ & $4.80 \pm 0.25$ & $9.06 \pm 0.15$ & 0.000 \\
\hline TAS (mm ol/h) & $1.79 \pm 0.12$ & $0.62 \pm 0.13$ & $0.88 \pm 0.10$ & $1.29 \pm 0.17$ & 0.000 \\
\hline
\end{tabular}

K: distilled water; P0: STZ 65 mg/kgBW and distilled water; P1: STZ $65 \mathrm{mg} / \mathrm{kgBW}$ and $200 \mathrm{mg} / \mathrm{kgBW}$ of rind extract; P2: STZ $65 \mathrm{mg} / \mathrm{kgBW}$ and $200 \mathrm{mg} / \mathrm{kgBW}$ of pulp extract. TAS = total antioxidant status; significantly different $(\mathrm{p}<0.05)$

On determination of serum total antioxidants it was found that the differences were statistically significant $(\mathrm{p}=0.000)$. Thus serum total antioxidants of the control and treatment groups were $1.79 \pm 0.12 \mathrm{mmol} / \mathrm{L}, 0.62 \pm 0.13 \mathrm{mmol} / \mathrm{L}$, $0.88 \pm 0.10 \mathrm{mmol} / \mathrm{L}$ and $1.29 \pm 0.17 \mathrm{mmol} / \mathrm{L}$, respectively. Total antioxidant status at 1.79 $\mathrm{mmol} / \mathrm{L}$ in the control group was significantly different from that of the treatment groups, and was also significantly different between the treatment groups $(\mathrm{p}<0.05)$ (Table 2).

The positive effects of Aloe vera extract in reducing the levels of 8-oxo-dG and increasing the total antioxidant status of diabetic rats are presented in Figure 1. From the graph it can be seen that the maximum level of 8-oxo-dG in diabetic rats was $19.75 \mathrm{ng} / \mathrm{mL}$. Treatment with Aloe vera extract decreased the level to $4.80 \mathrm{ng} /$
$\mathrm{mL}$ and $9.06 \mathrm{ng} / \mathrm{mL}$, respectively. The Aloe vera extract exerted a positive effect in increasing TAS in diabetic rats from 0.62 to 0.88 and 1.29 , respectively.

\section{DISCUSSION}

The present study showed that the blood glucose levels in diabetic rats were significantly higher than those in non diabetic rats. Aloe vera rind and pulp extract at a dose of $200 \mathrm{mg} / \mathrm{kgBW} /$ day for four weeks given to diabetic rats could significantly decrease the blood glucose level towards normality $(<200 \mathrm{~g} / \mathrm{dL})$. The effect of Aloe vera extract on glycemic control in animal models has been proven by a number of authors. ${ }^{(20-22)}$ It has also been reported that Aloe vera extract can stimulate the regeneration of

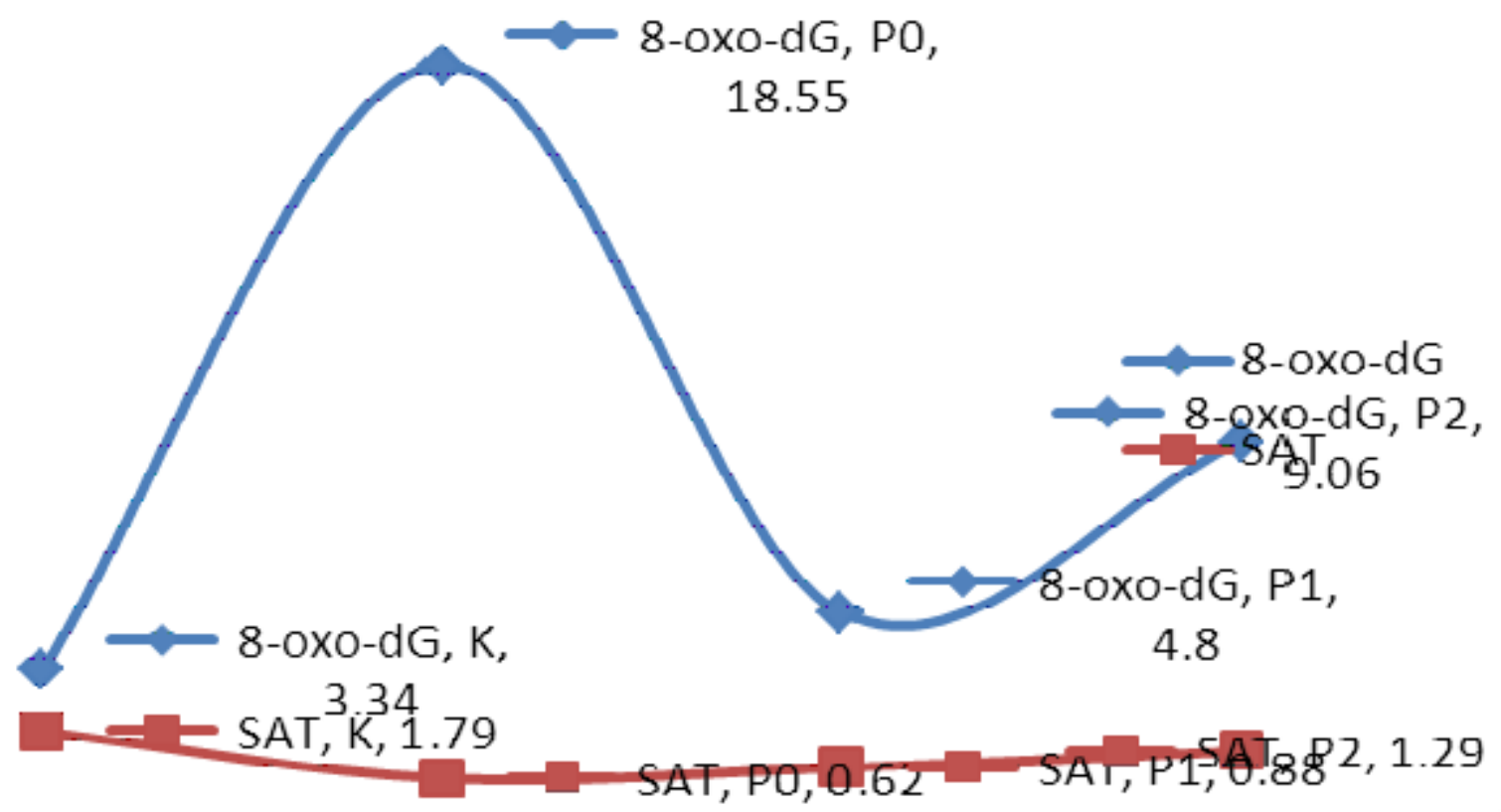

Figure 1.Graph of 8-oxo-dG levels and total antioxidant status (TAS)

Note: $\mathrm{SAT}=$ Indonesian term for TAS 
pancreatic $\beta$ cells and improve serum antioxidant enzyme levels, thus preventing pancreatic cell damage in diabetics. ${ }^{(16)}$

The 8-oxo-dG levels in diabetic rats in the present study were significantly higher than in normal rats or treatment groups receiving Aloe vera extract. The 8-oxo-dG levels increased to maintain the homeostasis mechanism in response to excessive DNA damage. Analysis of the levels of urinary 8-oxo-dG may reflect on DNA repair mechanisms. ${ }^{(23)}$ However, hyperglycemia in DM stimulates ROS, which leads to the activation of ROS generation and oxidative damage. These results are similar to those of previous reports. ${ }^{(24,25)}$

The free radicals produced by the normal metabolic processes are maintained in balance by endogenous and exogenous antioxidants that act as free radical scavengers. Oxidative stress occurs when the concentration of free radicals exceeds the detoxifying capacity of cellular antioxidants. ${ }^{(26)}$ Increased oxidative stress as a hyperglycemic condition may be one factor in the emergence of complications of diabetes. Oxidative damage is generally associated with the formation of $\mathrm{OH}$ that can cause oxidative damage to cellular components such as lipids, proteins and DNA. ${ }^{(27)}$

The reduced levels of 8-oxo-dG in the groups of diabetic rats treated with Aloe vera extract show that Aloe vera extract contains antioxidants that can protect cells from free radical influence during hyperglycemia. The hypoglycemic effect of Aloe vera which is obtained by stimulating pancreatic $\beta$ cell regeneration, increases the resistance of the cells, mitochondrial activity, and insulin production. ${ }^{(2,15)}$ In addition, inhibition of pancreatic amylase activity in the gut reduces the breakdown of carbohydrates into glucose. ${ }^{(21)}$

Oxidative stress that occurs because of a hyperglycemic state causes lipid peroxidation of the cell membrane, thus damaging the DNA. Active oxygen and other agents that generate free oxygen radicals are able to induce a variety of lesions in the DNA that cause deletions, mutations and other genetic effects. Defects that are specific for the DNA have shown that the sugar and basic groups making up the DNA are susceptible to oxidation. ${ }^{(28)}$

In the present study, mean TAS in the diabetic groups was lower than that in the control group. The diabetic groups $\mathrm{P} 1$ and $\mathrm{P} 2$ receiving Aloe vera extract had a higher total antioxidant status than the diabetic group $\mathrm{P} 0$ not receiving the extract. Aloe vera extract has a tendency to increase the total antioxidant levels in diabetic rats along with a significant increase in the levels of glutathione, superoxide dismutase (SOD), catalase, glutathione peroxidase and glutathioneS-transferase in the liver and kidneys of diabetic rats. ${ }^{(13)}$ These results are similar to those of previous reports, where enzyme activity of SOD, catalase, and glutathione increased significantly after administration of ethanolic Aloe vera extract to prevent glycation. ${ }^{(29)}$

The hyperglycemic condition in diabetes increases the concentration of free radicals that reduce endogenous antioxidants. Humans and animals have an antioxidant pool consisting of enzymatic antioxidants such as SOD, glutathione peroxidase (GPx), glutathione reductase (GR), and catalase (CAT), and non-enzymatic antioxidants including glutathione (GSH), vitamin $\mathrm{C}$ and vitamin E. (27) Exogenous antioxidants obtained from outside the body include micronutrients, vitamin $\mathrm{E}$, vitamin $\mathrm{C}$, minerals, carotenoids and flavonoids. ${ }^{(10)}$ Superoxide dismutase, catalase and glutathione peroxidase reduce ROS by converting ROS into stable compounds. The role of SOD is to catalyze the transformation of superoxide radicals $\left(\mathrm{O}_{2}\right.$ "') to hydrogen peroxide $\left(\mathrm{H}_{2} \mathrm{O}_{2}\right)$, which is then converted by the enzyme catalase into water and oxygen molecules. ${ }^{(30)}$

The presence of free radicals (ROS) can be overcome by involving both exogenous antioxidants and endogenous origin. Antioxidants are a group of substances that even at low concentrations would significantly impede or delay the oxidative process. ${ }^{(28)}$ One treatment that was developed in the management of diabetes used antioxidant therapy either from foods or 
supplements. Foods such as vegetables and fruits are known to have many components of active substances that are useful for the treatment.

Aloe vera, which is known as one of the plants that have antioxidant components such as phenolics, coumarins, flavonoids, polyfunctional organic acids, and tocopherol, can reduce lipid peroxidation in cell membranes, ${ }^{(26)}$ thus increasing the cellular antioxidants. ${ }^{(13)}$ Consumption of vitamin $\mathrm{E}$ has been shown to prevent cell damage by inhibiting lipid peroxidation, protein oxidation, protein glycation and platelet aggregation. ${ }^{(31)}$

A limitation of this study was that it did not analyze other factors that influence oxidative stress, such as hormones and inflammatory status, and did not examine seminogram parameters in hyperglycemic conditions. The clinical implication of this study is that oxidative stress may presumably stimulate apoptosis in testicular germ cells, thus affecting the quality of the produced sperm. Further research needs to be done to determine the factors affecting the quality of sperm (that are highly susceptible to oxidative stress) in order to reveal the fertility status of the male diabetic.

\section{CONCLUSION}

The study demonstrated that Aloe vera rind and pulp extracts can prevent the effect of oxidative stress in diabetic rat testis by lowering the concentration of free radicals (8-oxo-dG) and improving the TAS.

\section{CONFLICT OF INTEREST}

None declared.

\section{ACKNOWLEDGEMENT}

The author wish to thank DIPA PNBP UNNES (Daftar Isian Pelaksanaan Anggaran Pendapatan Negara Bukan Pajak Universitas Negeri Semarang) for the year 2016, which has provided the research funds.

\section{CONTRIBUTORS}

WC contributed to drafting the manuscript and design of the study. WC and AM contributed to data collecting, analysis and interpretation. $\mathrm{AD}$ and WI contributed revising the manuscript. WC wrote the manuscript and all authors read and approved the final version of the manuscript.

\section{REFERENCES}

1. Giacco F, Brownlee M. Oxidative stress and diabetic complications. Circ Res 2010;107: 1058-70.

2. Turrens JF. Mitochondrial formation of reactive oxygen species. J Physiol 2003;552:335-44.

3. Sun J, Lou X, Wang H, et al. Serum 8-hydroxy22 -deoxyguanosine (8-oxo-dG) levels are elevated in diabetes patients. Int J Diabetes Dev Ctries 2011;35:368-71.

4. Chan SS, Byung SM, Kyong SP, et al. Serum 8-hydroxy-guanine levels are increased in diabetic patients. Diabetes Care 2001;24:7337.

5. Liu X, Gan W, Zou Y, et al. Elevated levels of urinary markers of oxidative DNA and RNA damage in type 2 diabetes with complications. Oxidative Med Cell Longevity 2016, Article ID 4323198,7 pages. http://dx.doi.org/10.1155/ 2016/4323198.

6. Simone S, Gorin Y, Velagapudi C, et al. Mechanism of oxidative DNA damage in diabetes: tuberin inactivation and down regulation of DNA repair enzyme 8-oxo-7,8dihydro-2-deoxyguanosine-DNA glycosylase. Diabetes 2008;57:2626-36.

7. Hussein J, El-Khayat Z, Taha M, et al. Insulin resistance and oxidative stress in diabetic rats treated with flaxseed oil. J Med Plants Res 2012; 6:5499-506.

8. Smart DJ, Chipman JK, Hodges NJ. Activity of OGG1 variants in the repair of prooxidantinduced 8-oxo-2'-deoxyguanosine. DNA Repair 2006;5:1337-45.

9. Maritim A, Sanders R, Watkins J. Diabetes, oxidative stress, and antioxidants: a review. J Biochem Mol Tox 2003;17:24-38.

10. Pham-Huy LA, He H, Pham-Huy C. Free radicals, antioxidants in disease and health. Int J Biomed Sci 2008;4:89-96.

11. Wu JH, Ward NC, Indrawan AP, et al. Effects of $\alpha$-tocopherol and mixed tocopherol supplementation on markers of oxidative stress 
and inflammation in type 2 diabetes. Clin Chem 2007;3:511-9.

12. Mandal S, Yadav S, Yadav S, et al. Antioxidants: a review. J Chem Pharm Res 2009;1:102-4.

13. Rajasekaran S, Sivagnanam K, Subramanian S. Antioxidant effect of Aloe vera gel extract in streptozotocin-induced diabetes in rats. Pharmacol Report 2005;57:90-6.

14. Rodriguez E, Darias Martin J, Diaz Romero C. Aloe vera as a functional ingredient in foods. Crit Rev Food Sci Nutr 2010;50:305-26.

15. Rahimifard M, Navaei-Nigjeh M, Mahroui N. Improvement in the function of isolated rat pancreatic islets through reduction of oxidative stress using traditional Iranian medicine. Cell J 2013;16:147-63.

16. Mohapatra S, Pradhan S, Rath B, et al. Antioxidant properties of Aloe vera in streptozotocin induced diabetic rats. Int J Pharm Bio Sci 2013;4:87-91.

17. Prueksrisakul T, Chantarangsu S, Thunyakitpisal P. Effect of daily drinking of Aloe vera gel extract on plasma total antioxidant capacity and oral pathogenic bacteria in healthy volunteer : a shortterm study. J Complem Integr Med 2015;12:159_ 64. DOI: https://doi.org/10.1515/jcim-20140060 .

18. World Health Organization. Definition and diagnosis of diabetes mellitus and intermediate hyperglycemia. Geneva, Switzerland: World Health Organization;2011.

19. Ghasemi A, Khalifi S, Jedi S. Streptozotocinnicotinamide induced rat model of type 2 diabetes. Acta Physiol Hungaria 2014;101:408 20.

20. Enas AKM. Antidiabetic, antihypercholestermic and antioxidative effect of Aloe vera gel extract in alloxan induced diabetic rats. Aust J Basic Appl Sci 2011;5:1321-7.

21. Abo-Youssef AMH, Messiha BAS. Beneficial effects of Aloe vera in treatment of diabetes: comparative in vivo and in vitro studies. Bull Fac Pharm 2013;51:7-11.
22. Edogbanya IHN, Ocholi OJ, Apeji Y. Comparative study on the single and combined effects of leaf extracts of Aloe vera and Vernonia amygdalina on blood glucose level and histology of the pancreas in alloxan-induced diabetic Wistar rats. Adv Agriculture Sci Eng Res 2014;4: 1687-94.

23. Roszkowski K, Jozwicki W, Blaszczyk P, et al. Oxidative damage DNA: 8-oxo Gua and 8-oxo $\mathrm{dG}$ as molecular markers of cancer. Med Sci Monit 2011;17:329-33.

24. Kilarkaje N, Al-Hussaini H, Al-Bader MM. Diabetes-induced DNA damage and apoptosis are associated with poly (ADP ribose) polymerase 1 inhibition in the rat testis. Eur J Pharmacol 2014;737:29-40.

25. Araki E, Nishikawa T. Oxidative stress: a cause and therapeutic target of diabetic complications. J Diabetes Invest 2010;1:90-6.

26. Halliwell B. Free radicals and antioxidants - quo vadis? Trends Pharmacol Sci 2011;32:125-30.

27. Halliwell B, Gutteridge JMC, editors. Free radicals in biology and medicine. $4^{\text {th }} \mathrm{ed}$. Oxford: Clarendon Press;2007.

28. Kumar S. Free radicals and antioxidants: human and food system. Adv Appl Sci Res 2011;2:12935 .

29. Ramachandraiahgari RMY, Somesula SR, Adi PJ, et al. Protective role of ethanolic extract of Aloe vera antioxidant properties on liver and kidney of streptozotocin-induced diabetic rats. Digest J Nanomaterials Biostructures 2012;7: 175-84.

30. Darmawan H. Production of ROS and its effects on mitochondrial and nuclear DNA, human spermatozoa, and sperm function. Med J Indones 2007;16:127-33.

31. Minamiyama Y, Takemura S, Bito Y, et al. Supplementation of $\alpha$-tocopherol improves cardiovascular risk factors via the insulin signalling pathway and reduction of mitochondrial reactive oxygen species in type II diabetic rats. Free Radic Res 2008;42:261-71. 